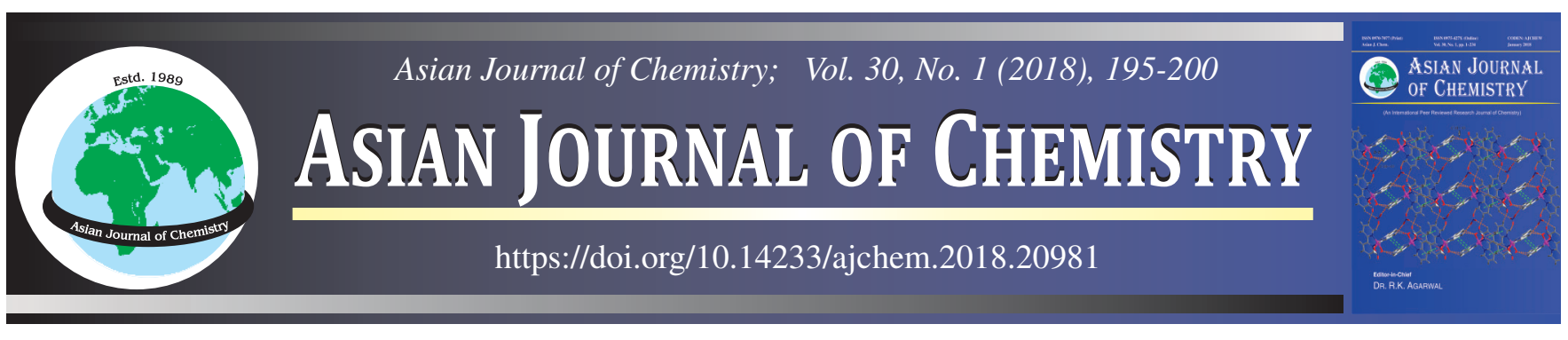

\title{
Design, Synthesis and Hydrolysis Study of Gatifloxacin-NSAIDs as Mutual Prodrugs
}

\author{
NoOR H. NASER
}

Department of Pharmaceutical Chemistry, Faculty of Pharmacy, University of Kufa, Kufa, Iraq

Corresponding author: E-mail: noorh.naser@uokufa.edu.iq; noorhatef@yahoo.com

\begin{abstract}
Four different well-known non-steroidal anti-inflammatory drugs (naproxen, ketoprofen, diclofenac and ibuprofen) were linked to gatifloxacin anti-infective drug which possess anti-inflammatory activity, using chloroacetyl chloride as spacer, in order to synthesize a novel mutual prodrugs that give synergestic anti-inflammatory effect, in addition to temporary mask the carboxyl group of the non-steroidal drugs, which reduce the gastric ulceration and bleeding. The chemical structures of the synthesized compounds were confirmed and characterized using FT-IR spectroscopy, ${ }^{1} \mathrm{H}$ NMR spectroscopy, elemental microanalysis, melting points and $\mathrm{R}_{\mathrm{f}}$ values. in vitro hydrolysis study of the synthesized mutual prodrugs was performed at different $\mathrm{pHs}(1.2$ and 7.4$)$, which reveal the chemical stability of these compounds inside the gastrointestinal tract. While their hydrolysis in $80 \%$ human plasma, was revealed rapid conversion of the four synthesized prodrugs inside blood circulation to give the parent drug molecules, with about $40-55 \%$ hydrolysis occur in the first hour.

Keywords: Gatifloxacin, Prodrugs, Flouroquinolones, Non-steroidal anti-inflammatory drugs.
\end{abstract}

\section{INTRODUCTION}

Mutual prodrug is inactive compound consisting of two parts, each part possess specific therapeutic activity when it present alone [1]. The two parts linked together either directly, or by a specific linker to reduce the steric effect between the two molecules [2]. The most predominant bond that used to join the two moieties is the ester bond, as it is easily hydrolyzed by esterase enzyme after reaching to the blood circulation [3]. Mutual prodrugs aimed to potentiate the therapeutic action and provide synergistic effect for treatment of certain disease $[4,5]$, reduce the dose of the therapeutically active compounds, improve the drugs efficacy, optimizing delivary [6] and alleviate the side effects associated with drug molecules such as non-steroidal anti-inflammatory drugs [7], which are used for treatment of different inflammatory conditions as osteoarthritis and rheumatoid arthritis [8]. These drugs caused gastric mucosal ulceration and bleeding [9], due to presence of carboxyl group in the most of non-selective non-steroidal anti-inflammatory drugs as ketoprofen [10], naproxen [11,12], ibuprofen [13] and diclofenac [14]. Therefore the temporary masking of this group through linking with other compound will reduce their gastric ulceration [15].

Fluoroquinolones are synthetic antibacterial agents, which are acting through inhibition of bacterial cell replication $[16,17]$, through suppression of topoisomerase enzymes which considred the key enzymes that responsible for DNA supercoiling [18], by that prevent bacterial DNA replication and transcription, which lead to cell apoptosis [19]. Fluoroquinolones as ciprofloxacin [20] and gatifloxacin [21], inhibit gyrase or topoisomerase II enzyme in gram negative bacteria [22], while they inhibit topoisomerase IV in gram positive bacteria [23]. Gatifloxacin is bactericidal drug belong to the fourth generation flouroquinolones antibacterial group [24]. It possess extended antimicrobial spectrum, because it is effective against both gram negative and gram positive bacteria [25], in addition to its effectiveness against anaerobic pathogen, bacteriodes-fragilis, mouth anaerobes [26] and a typical bacteria as Mycoplasma pneumonia [27]. This activity will attributed to the methoxy group that substituted the hydrogen atom at C8 position of quinolone ring [28]. It considered as second line in eradication of tuberculosis in combination with rifampicin or isoniazid, due to its effectiveness against Mycobacterium tuberculosis [29].

It was found in addition to the antimicrobial effect of gatifloxacin, it possess strong anti-inflammatory properties [30], by its ability to suppress the release of the inflammatory cytokines from monocytes, macrophage or peripheral lymphocytes [31]. It shows inhibitory activity toward the release of TNF- $\alpha$ and other types of inflammatory mediators [32]. Depen-ding on this background, four NSAIDs were linked to gatiflo-xacin, through chloroacetyl chloride as spacer, to 
synthesize mutual prodrugs, in order to ameliorate the gastric ulceration and bleeding associated with the use of NSAIDs, by esterifi-cation of the carboxyl group, in addition to potentiate the anti-inflammatory activity and give synergistic effect.

\section{EXPERIMENTAL}

The solvents (anhydrous) and chemicals were of analytical grade and provided from (Merck Germany; Sigma-Aldrich Germany; Fluka Switzerland). Melting points were recorded by capillary tube using thomas hover apparatus (England). Retention factor $\left(\mathrm{R}_{\mathrm{f}}\right)$ values were measured through using ascending thin layer chromatography, to ensure the purity and progress of the reaction, using ethyl acetate:ethanol (2:3) as mobile phase [33]. Infrared spectra were recorded at college of pharmacy, Kufa University, using Fourier transform infrared (FT-IR) spectrophotometer, by $\mathrm{KBr}$ discs. Proton nuclear magnetic resonance $\left({ }^{1} \mathrm{H}\right.$ NMR) spectra were recorded using NMR ultra shield spectrophotometer $500 \mathrm{MHz}$, Bruker Avance III (Switzerland) and elemental microanalysis (CHNO) was recorded using a euro 3000 elemental analyzer (Italy).

Steps of the synthesis of four target compounds and their intermediates were presented in Scheme-I. The carboxyl group of gatifloxacin was protected in the form of methyl ester, through reaction with thionyl chloride in cold methanol to form an ester, which was undergo reaction with chloroacetyl chloride to give compound II that reacted with four different non-steroidal anti-inflammatory drugs (NSAIDs) to give the final target compounds.

Synthesis of methyl-1-cyclopropyl-6-fluoro-8-methoxy7-(3-methylpiperazin-1-yl)-4-oxo-1,4-dihydroquinoline-3carboxylate (I): Gatifloxacin ( $2 \mathrm{~g}, 5.33 \mathrm{mmol})$, was dissolved in methanol $(50 \mathrm{~mL})$, the solution cold to- $15{ }^{\circ} \mathrm{C}$, then thionyl chloride $(0.38 \mathrm{~mL}, 5.33 \mathrm{mmol})$ was added drop-wise. The reaction mixture kept for $3 \mathrm{~h}$ at $40^{\circ} \mathrm{C}$, then undergo reflux for $3 \mathrm{~h}$ and left overnight at room temperature. Methanol was evaporated and the residue was redissolved in methanol and evaporated. The process was repeated until complete removal of thionyl chloride was achieved. The product crystallized using ether-ethanol [34]. The description and physical parameters were represented in Table-1. FT-IR $\left(\mathrm{cm}^{-1}\right): 3217(\mathrm{~N}-\mathrm{H})$ stretching of secondary amine, $3010(\mathrm{C}-\mathrm{H})$ stretching of aromatic, 1743 $(\mathrm{C}=\mathrm{O})$ stretching of ester, $1724(\mathrm{C}=\mathrm{O})$ stretching of ketone. CHNO calculated $\left(\mathrm{C}_{20} \mathrm{H}_{24} \mathrm{~N}_{3} \mathrm{O}_{4} \mathrm{~F}\right)$ : C, 61.68; $\mathrm{H}, 6.21 ; \mathrm{N}, 10.79$; O, 16.43 found: C, 62.05; H, 6.16; N, 10.74; O, 16.34; ${ }^{1} \mathrm{H}$ NMR $\left(\mathrm{DMSO}-d_{6}\right) \delta(\mathrm{ppm}): 8.68(\mathrm{~s}, 1 \mathrm{H}, \mathrm{C}=\mathrm{C}-\mathrm{H}), 7.66(\mathrm{~s}, 1 \mathrm{H}, \mathrm{Ar}-\mathrm{H})$, $4.12\left(\mathrm{~m}, 1 \mathrm{H}, \mathrm{CH}\right.$ of cyclopropyl), $3.83\left(\mathrm{~s}, 3 \mathrm{H}, \mathrm{O}-\mathrm{CH}_{3}\right), 3.74$ (s, $\left.3 \mathrm{H}, \mathrm{COO}-\mathrm{CH}_{3}\right), 3.54-2.68\left(\mathrm{~m}, 7 \mathrm{H}, \mathrm{CH}_{2}\right.$ and $\mathrm{CH}$ of piperazine), 1.33-1.08 (m, $4 \mathrm{H}, \mathrm{CH}_{2}$ of cyclopropyl), 1.1 (d, $\left.3 \mathrm{H}, \mathrm{CH}_{3}\right), 1.08$ (m, 1H, NH).

Synthesis of methyl 7-[4-(2-chloroacetyl)-3-methylpiperazin-1-yl]-1-cyclopropyl-6-fluoro-8-methoxy-4-oxo1,4-dihydroquinoline-3-carboxylate (II): Compound I (1 g, $2.5 \mathrm{mmol})$ was dissolved in DMF: $\mathrm{CHCl}_{3}(25: 75)(30 \mathrm{~mL})$ and TEA $(0.34 \mathrm{~mL}, 2.5 \mathrm{mmol})$ was added. The mixture was stirred in ice bath and chloroacetyl chloride $(0.2 \mathrm{~mL}, 2.5 \mathrm{mmol}$ in $10 \mathrm{~mL}$ chloroform) was added drop-wise over a period of $1 \mathrm{~h}$, followed by reflux for $3 \mathrm{~h}$. Then the solvent was evaporated and the residue was collected and crystallized by using ethanol [35].<smiles></smiles><smiles>CC(C)Cc1ccc(C(C)(C)C(=O)O)cc1</smiles>
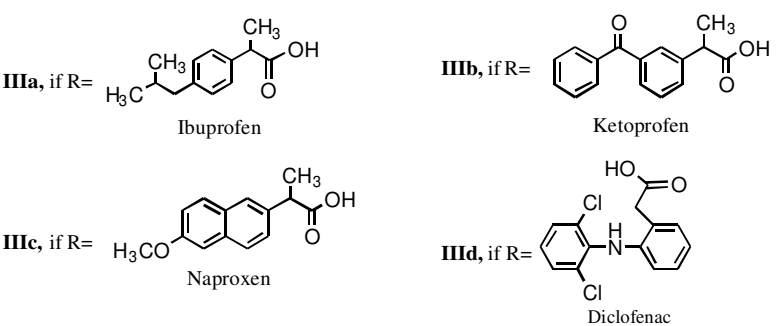

Scheme-I: Synthesis of target compounds (IIIa-IIId) and their intermediates

The description and physical parameters were represented in Table-1. FT-IR $\left(\mathrm{cm}^{-1}\right)$ : $3012(\mathrm{C}-\mathrm{H})$ stretching of aromatic, 1740 $(\mathrm{C}=\mathrm{O})$ stretching of ester, $1720(\mathrm{C}=\mathrm{O})$ stretching of ketone, $1643(\mathrm{C}=\mathrm{O})$ stretching of amide, $847(\mathrm{C}-\mathrm{Cl})$ stretching. $\mathrm{CHNO}$ calculated $\left(\mathrm{C}_{22} \mathrm{H}_{25} \mathrm{~N}_{3} \mathrm{O}_{5} \mathrm{ClF}\right)$ : C, 56.71; H, 5.41; N, 9.02; O, 17.17 found: C, 56.95; H, 5.36; N, 8.94; O, 17.10; ${ }^{1} \mathrm{H}$ NMR $\left(\mathrm{DMSO}-d_{6}\right) \delta(\mathrm{ppm}): 8.68(\mathrm{~s}, 1 \mathrm{H}, \mathrm{C}=\mathrm{C}-\mathrm{H}), 7.66(\mathrm{~s}, 1 \mathrm{H}, \mathrm{Ar}-\mathrm{H})$, $4.12\left(\mathrm{~m}, 1 \mathrm{H}, \mathrm{CH}\right.$ of cyclopropyl), 3.83 (s, 3H, O- $\left.\mathrm{CH}_{3}\right), 3.71$ (s, 3H, COO- $\mathrm{CH}_{3}$ ), 3.7 (s, $\left.2 \mathrm{H}, \mathrm{CH}_{2}-\mathrm{Cl}\right), 3.67-3.31\left(\mathrm{~m}, 7 \mathrm{H}, \mathrm{CH}_{2}\right.$ and $\mathrm{CH}$ of piperazine), $1.33-1.07\left(\mathrm{~m}, 4 \mathrm{H}, \mathrm{CH}_{2}\right.$ of cyclopropyl), $1.1\left(\mathrm{~d}, 3 \mathrm{H}, \mathrm{CH}_{3}\right)$.

Coupling reaction of compound II with NSAIDs (IIIaIIId): A mixture of compound II ( $2 \mathrm{~g}, 4.3 \mathrm{mmol})$ and NSAID (4.3 mmol), were dissolved in DMF (20 mL), then TEA (0.6 $\mathrm{mL}, 4.3 \mathrm{mmol}$ ) was added. The reaction mixture was stirred overnight at room temperature. The solvent was evaporated and the residue was collected and crystallized with ethanol [35]. The description and physical parameters were represented in Table-1.

Methyl 1-cyclopropyl-6-fluoro-7-(4-(2-((2-(4-isobutylphenyl)propanoyl)oxy) acetyl)-3-methylpiperazin-1-yl)-8methoxy-4-oxo-1,4-dihydroquinoline-3-carboxylate (IIIa): FT-IR $\left(\mathrm{cm}^{-1}\right)$ : 2976 and $2832(\mathrm{C}-\mathrm{H})$ stretching of alkane, 1748 $(\mathrm{C}=\mathrm{O})$ stretching of ketone overlape with $(\mathrm{C}=\mathrm{O})$ stretching of ester, $1690(\mathrm{C}=\mathrm{O})$ of amide. $\mathrm{CHNO}$ calculated $\left(\mathrm{C}_{35} \mathrm{H}_{42} \mathrm{~N}_{3} \mathrm{O}_{7} \mathrm{~F}\right)$ : 
TABLE-1

PHYSICO-CHEMICAL PROPERTIES OF THE SYNTHESIZED COMPOUNDS

\begin{tabular}{clllccc}
\hline Compound & \multicolumn{1}{c}{ m.f. } & m.w. & \multicolumn{1}{c}{ Description } & Yield $(\%)$ & m.p. $\left({ }^{\circ} \mathrm{C}\right)$ & $\mathrm{R}_{\mathrm{f}}$ values \\
\hline I & $\mathrm{C}_{20} \mathrm{H}_{24} \mathrm{~N}_{3} \mathrm{O}_{4} \mathrm{~F}$ & 389.42 & Pale yellow crystals & 83.6 & $190-192$ & 0.75 \\
II & $\mathrm{C}_{22} \mathrm{H}_{25} \mathrm{~N}_{3} \mathrm{O}_{5} \mathrm{ClF}$ & 465.91 & Pale yellow powder & 85.0 & $200-203$ & 0.89 \\
IIIa & $\mathrm{C}_{35} \mathrm{H}_{42} \mathrm{~N}_{3} \mathrm{O}_{7} \mathrm{~F}$ & 635.73 & Faint brown oil & 55.0 & - & 0.70 \\
IIIb & $\mathrm{C}_{38} \mathrm{H}_{38} \mathrm{~N}_{3} \mathrm{O}_{8} \mathrm{~F}$ & 683.73 & Faint yellow oil & 46.0 & - & 0.92 \\
IIIc & $\mathrm{C}_{36} \mathrm{H}_{38} \mathrm{~N}_{3} \mathrm{O}_{8} \mathrm{~F}$ & 659.71 & Dark yellow powder & 48.5 & $135-138$ & 0.75 \\
IIId & $\mathrm{C}_{36} \mathrm{H}_{35} \mathrm{~N}_{4} \mathrm{O}_{7} \mathrm{Cl} \mathrm{Cl}_{2} \mathrm{~F}$ & 725.60 & Dark yellow powder & 38.6 & $137-140$ & 0.84 \\
\hline
\end{tabular}

C, 66.13; H, 6.66; N, 6.61; O, 17.62 found: C, 65.95; H, 6.61; $\mathrm{N}, 6.56 ; \mathrm{O}, 17.74 ;{ }^{1} \mathrm{H}$ NMR (DMSO- $\left.d_{6}\right) \delta(\mathrm{ppm}): 8.68(\mathrm{~s}, 1 \mathrm{H}$, $\mathrm{C}=\mathrm{C}-\mathrm{H}), 7.69$ (s, 1H, Ar-H of gatifloxacin), 7.17-7.12 (m, 4H, Ar-H of ibuprofen), 4.97 (s, 2H, O- $\left.\mathrm{CH}_{2}\right), 4.12$ (m, 1H, CH of cyclopropyl), $3.83\left(\mathrm{~s}, 3 \mathrm{H}, \mathrm{O}-\mathrm{CH}_{3}\right), 3.71\left(\mathrm{~s}, 3 \mathrm{H}, \mathrm{COO}-\mathrm{CH}_{3}\right), 3.71$ (m, $1 \mathrm{H}, \mathrm{CH}), 3.67-3.28\left(\mathrm{~m}, 7 \mathrm{H}, \mathrm{CH}_{2}\right.$ and $\mathrm{CH}$ of piperazine), 2.43 $\left(\mathrm{d}, 2 \mathrm{H}, \mathrm{CH}_{2}\right), 1.8(\mathrm{~m}, 1 \mathrm{H}, \mathrm{CH}), 1.52-1.30\left(2 \mathrm{~d}, 6 \mathrm{H}, 2 \times\left[\mathrm{CH}_{3}\right]\right)$, 1.33-1.09 (m, 4H, $\mathrm{CH}_{2}$ of cyclopropyl), $0.88\left(\mathrm{~d}, 6 \mathrm{H}, 2 \times\left[\mathrm{CH}_{3}\right]\right)$.

Methyl 7-(4-(2-((2-(3-benzoylphenyl)propanoyl)oxy)acetyl)-3-methylpiperazin-1-yl)-1-cyclopropyl-6-fluoro-8methoxy-4-oxo-1,4-dihydroquinoline-3-carboxylate (IIIb): FT-IR $\left(\mathrm{cm}^{-1}\right)$ : $3001(\mathrm{C}-\mathrm{H})$ stretching of aromatic, 2987 and 2839 $(\mathrm{C}-\mathrm{H})$ stretching of alkane, $1728(\mathrm{C}=\mathrm{O})$ stretching of ketone, $1717(\mathrm{C}=\mathrm{O})$ stretching of ester, $1681(\mathrm{C}=\mathrm{O})$ stretching of amide. CHNO calculated $\left(\mathrm{C}_{38} \mathrm{H}_{38} \mathrm{~N}_{3} \mathrm{O}_{8} \mathrm{~F}\right): \mathrm{C}, 66.75 ; \mathrm{H}, 5.6 ; \mathrm{N}, 6.15$; $\mathrm{O}, 18.72$ found: $\mathrm{C}, 67.02 ; \mathrm{H}, 5.56 ; \mathrm{N}, 6.20 ; \mathrm{O}, 18.6 ;{ }^{1} \mathrm{H}$ NMR $\left(\mathrm{DMSO}-d_{6}\right) \delta(\mathrm{ppm}): 8.69$ (s, $\left.1 \mathrm{H}, \mathrm{C}=\mathrm{C}-\mathrm{H}\right), 7.84-7.34(\mathrm{~m}, 10 \mathrm{H}$, Ar-H), 4.7 (s, 2H, O-CH $), 4.12$ (m, 1H, CH of cyclopropyl), 3.84 (s, 3H, O-CH $\mathrm{CH}_{3}, 3.71$ (s, 3H, COO- $\mathrm{CH}_{3}$ ), 3.7 (m, $\left.1 \mathrm{H}, \mathrm{CH}\right)$, 3.69-3.28 (m, 7H, $\mathrm{CH}_{2}$ and $\mathrm{CH}$ of piperazine), 1.50-1.3 (2d, $\left.6 \mathrm{H}, 2 \times\left[\mathrm{CH}_{3}\right]\right), 1.33-1.08\left(\mathrm{~m}, 4 \mathrm{H}, \mathrm{CH}_{2}\right.$ of cyclopropyl).

Methyl 1-cyclopropyl-6-fluoro-8-methoxy-7-(4-(2-((2(6-methoxynaphthalen-2-yl)propanoyl)oxy)acetyl)-3methylpiperazin-1-yl)-4-oxo-1,4-dihydroquinoline-3carboxylate (IIIc): FT-IR $\left(\mathrm{cm}^{-1}\right): 3006(\mathrm{C}-\mathrm{H})$ stretching of aromatic, 2968 and $2825(\mathrm{C}-\mathrm{H})$ stretching of alkane, $1731(\mathrm{C}=\mathrm{O})$ stretching of ketone, $1723(\mathrm{C}=\mathrm{O})$ stretching of ester, $1686(\mathrm{C}=\mathrm{O})$ stretching of amide, 1130 (C-O-C) stretching of ether. CHNO calculated $\left(\mathrm{C}_{36} \mathrm{H}_{38} \mathrm{~N}_{3} \mathrm{O}_{8} \mathrm{~F}\right): \mathrm{C}, 65.54 ; \mathrm{H}, 5.81 ; \mathrm{N}, 6.37 ; \mathrm{O}, 19.40$ found: C, 65.71; H, 5.81; N , 6.33; O, 19.42; ${ }^{1} \mathrm{H} \mathrm{NMR}$ (DMSO-d $d_{6}$ ) $\delta(\mathrm{ppm}): 8.69$ (s, 1H, C=C-H), 7.78-7.06 (m, 7H, Ar-H), $4.97(\mathrm{~s}$, $\left.2 \mathrm{H}, \mathrm{O}-\mathrm{CH}_{2}\right), 4.12$ (m, 1H, CH of cyclopropyl), 3.83-3.81 (2s, $\left.6 \mathrm{H}, 2 \times\left[\mathrm{O}-\mathrm{CH}_{3}\right]\right), 3.71\left(\mathrm{~s}, 3 \mathrm{H}, \mathrm{COO}-\mathrm{CH}_{3}\right), 3.71(\mathrm{~m}, 1 \mathrm{H}, \mathrm{CH})$, 3.48-3.27 (m, 7H, $\mathrm{CH}_{2}$ and $\mathrm{CH}$ of piperazine), 1.57-131 (2d, $\left.6 \mathrm{H}, 2 \times\left[\mathrm{CH}_{3}\right]\right), 1.31-1.1\left(\mathrm{~m}, 4 \mathrm{H}, \mathrm{CH}_{2}\right.$ of cyclopropyl).

Methyl 1-cyclopropyl-7-(4-(2-(2-(2-((2,6-dichlorophenyl)amino)phenyl)acetoxy)acetyl)-3-methylpiperazin-1-yl)-6fluoro-8-methoxy-4-oxo-1,4-dihydroquinoline-3-carboxylate (IIId): FT-IR $\left(\mathrm{cm}^{-1}\right)$ : $3316(\mathrm{~N}-\mathrm{H})$ stretching of secondary amine, $3006(\mathrm{C}-\mathrm{H})$ stretching of aromatic, 2982 and 2843 $(\mathrm{C}-\mathrm{H})$ stretching of alkane, $1743(\mathrm{C}=\mathrm{O})$ stretching of ketone, $1730(\mathrm{C}=\mathrm{O})$ stretching of ester, $1682(\mathrm{C}=\mathrm{O})$ stretching of amide, 1091 (=C-CL) stretching vibration. CHNO calculated $\left(\mathrm{C}_{36} \mathrm{H}_{35} \mathrm{~N}_{4} \mathrm{O}_{7} \mathrm{Cl}_{2} \mathrm{~F}\right): \mathrm{C}, 59.59 ; \mathrm{H}, 4.86 ; \mathrm{N}, 7.72 ; \mathrm{O}, 15.43$ found: C, 59.55; H, 4.82; N, 7.74; O, 15.4; ${ }^{1} \mathrm{H}$ NMR (DMSO- $\left.d_{6}\right) \delta$ (ppm): 9.48 (s, 1H, NH), 8.69 (s, 1H, C=C-H), 7.69-6.76 (m, $8 \mathrm{H}, \mathrm{Ar}-\mathrm{H}), 4.97$ (s, 2H, O-CH $), 4.12$ (m,1H, CH of cyclopropyl), $3.83\left(\mathrm{~s}, 3 \mathrm{H}, \mathrm{O}-\mathrm{CH}_{3}\right), 3.71$ (high intensity singlet, $5 \mathrm{H}, \mathrm{O}_{-} \mathrm{CH}_{3}$ and $\mathrm{CH}_{2}-\mathrm{COO}$ ), $3.67-3.28$ (m, $7 \mathrm{H}, \mathrm{CH}_{2}$ and $\mathrm{CH}$ of piperazine), 1.31 (d, 3H, $\mathrm{CH}_{3}$ ), 1.3-1.1 (m, 4H, $\mathrm{CH}_{2}$ of cyclopropyl).

Chemical hydrolysis: The hydrolysis of the synthesized ester prodrugs was performed in $\mathrm{HCl}(\mathrm{pH}=1.2)$ and phosphate buffer $(\mathrm{pH}=7.4)$, which are near the $\mathrm{pH}$ of physiological fluids of gastrointestinal tract, which represented by stimulated gastric fluids and stimulated intestinal fluids respectively. The reaction was began by addition of $1 \mathrm{~mL}$ of stock solution $(1 \mathrm{mg} /$ $\mathrm{mL}$ ) of the synthesized ester prodrugs (IIIa-IIId) in methanol to preheated buffer solutions to obtain final concentration of $0.02 \mathrm{mg} / \mathrm{mL}$. About $3 \mathrm{~mL}$ of the prepared samples were withdrawn at appropriate intervals (15, 30, 60, 120 and $240 \mathrm{~min})$ and analyzed by using ultraviolet spectrophotometer [36,37].

Enzymatic hydrolysis (in plasma): The hydrolysis of the synthesized ester prodrugs was performed in human plasma (80\%), that previously diluted with isotonic phosphate buffer $(\mathrm{pH}=7.4)$ at $37{ }^{\circ} \mathrm{C}$. The reaction was began by addition of $1 \mathrm{~mL}$ of stock solution of the synthesized ester prodrugs in methanol to preheated plasma solution to obtain final concentration of $0.02 \mathrm{mg} / \mathrm{mL}$. The solution was kept at $37{ }^{\circ} \mathrm{C}$ in a water bath. About $3 \mathrm{~mL}$ of the prepared samples were withdrawn and de-proteinized by addition of $6 \mathrm{~mL}$ of cold methanol at appropriate intervals (15, 30, 60, 120 and $240 \mathrm{~min})$. Samples were mixed immediately and centrifuged for $5 \mathrm{~min}$, at 4000 rpm. The clear supernatant was withdrawn and analyzed by using ultraviolet spectrophotometer [36,37].

\section{RESULTS AND DISCUSSION}

The synthesis of the four final mutual prodrugs of gatifloxacin (IIIa-IIId) and their intermediates was illustrated in Scheme-I. Firstly, the carboxyl group of gatifloxacin was protected in the form of methyl ester through reaction with thionyl chloride in methanol to give acyl chloride intermediate which undergo reaction with methanol to give methyl ester of gatifloxacin. The shifting of $\mathrm{C}=\mathrm{O}$ stretching from 1722 to $1743 \mathrm{~cm}^{-1}$ and disappearance of broad band above $3200 \mathrm{~cm}^{-1}$, indicate the conversion of carboxyl group in gatifloxacin to its methyl ester derivative, this was supported by appearance of singlet signal at $3.83(\mathrm{ppm})$ for $\left(\mathrm{O}-\mathrm{CH}_{3}\right)$ in ${ }^{1} \mathrm{H}$ NMR spectrum $[38,39]$. The mechanism of esterification was illustrated in Schemes II and III [40]. Gatifloxacin methyl ester (compound I) undergo nucleophilic substitution reaction $\left(\mathrm{SN}^{2}\right)$ in presence of equimolar of chloroacetyl chloride, when the secondary cyclic amine of piperazine will attack the electrophilic carbonyl carbon in chloroacetyl chloride leading to displacement of chlorine atom. The reaction was occurred in presence of equimolar of triethylamine which act as a base to neutralize the hydrogen chloride formed, this reaction lead to formation of compound II.

The rate of an $\mathrm{SN}^{2}$ reaction follows second order kinetics, 


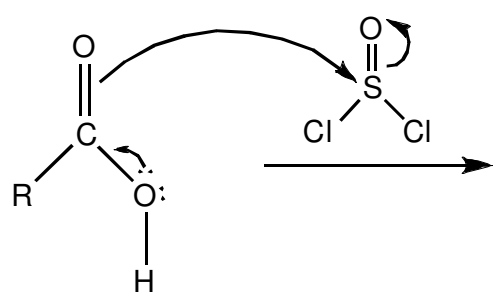

Carboxy lic acid<smiles>[R]C(=O)OS([O])(Cl)Cl</smiles>

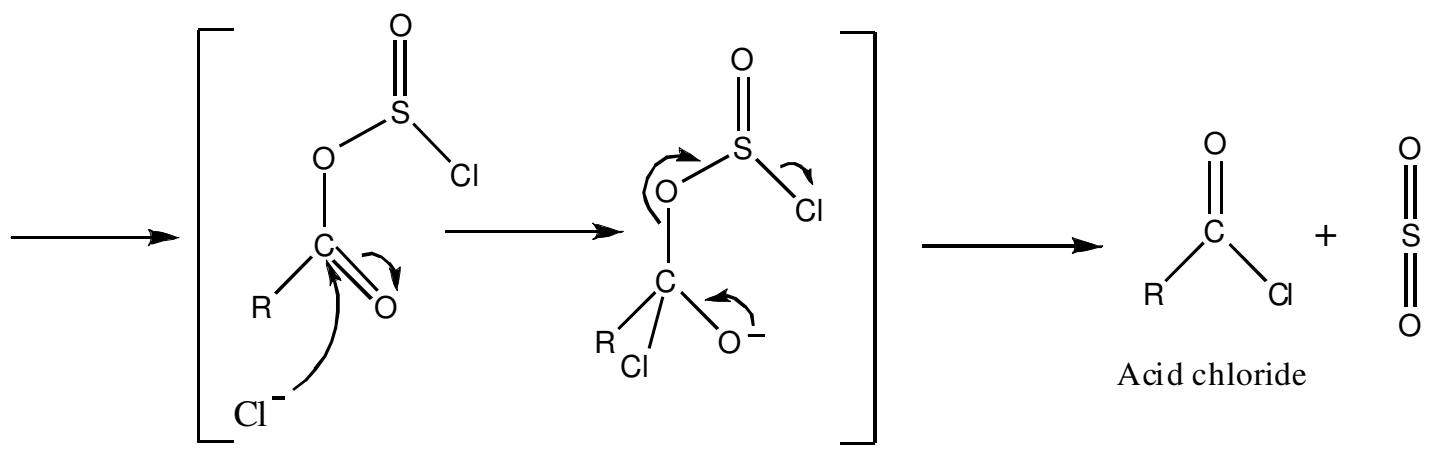

An acyl chlorosulfite

Scheme-II: Mechanism of conversion of carboxylic acid to acid chloride

as the rate limiting step depend on the nucleophile concentration,

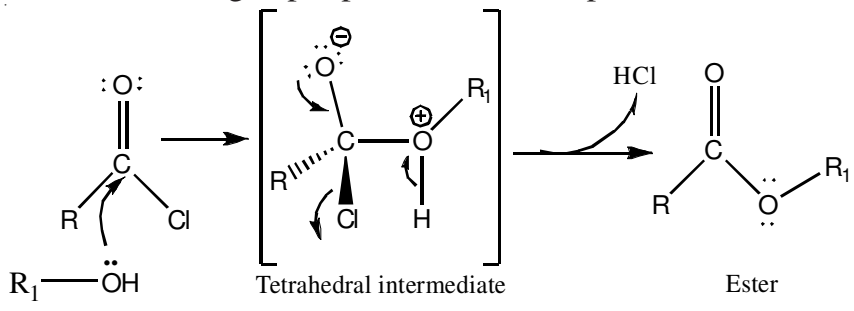

Scheme-III: Mechanism of conversion of acid chloride to an ester

as well as the concentration of the substrate [41]. This mechanism depends on solvent, temperature and concentration of the nucleophile and that of the leaving group. It is generally favoured in primary or secondary alkyl halides with an aprotic solvent as (DMF) [42]. In aliphatic heterocyclic compounds, the nitrogen atom is a part of a saturated heterocyclic ring and lone pair of electrons is available for reaction with protons (e.g. piperazine). Compounds of this type are similar in base strength to their openchain aliphatic counterparts with typical pKa values of 8-9 [43]. Compound II was reacted with four different acidic non-steroidal drugs, the free carboxyl groups converted directly into esters by $\mathrm{SN}^{2}$ reaction of a carboxylate ion with a primary alkyl halide in presence of base catalyst [44]. The shifting of $\mathrm{C}=\mathrm{O}$ stretching from lower frequencies to higher frequencies indicate the conversion of carboxylic acid groups to ester groups. The physical characters of the synthesized compounds as melting points and $\mathrm{R}_{\mathrm{f}}$ values were listed in Table- 1 .

Hydrolysis study: The hydrolysis behaviour of the four synthesized prodrugs (IIIa-IIId) was evaluated at different $\mathrm{pH}$ values and in human plasma, in order to determine their stability during passage through out gastrointestinal tract environment until reaching to the blood circulation. The kinetic study was performed by using ultraviolet spectroscopic method by recording the decrease in absorbance of gatifloxacin-NSAIDs prodrugs accompying the hydrolysis.

Chemical hydrolysis: The hydrolysis of the four synthesized gatifloxacin-NSAIDs in aquous solution of $\mathrm{HCl}(\mathrm{pH}=$ 1.2) and phosphate buffer solution $(\mathrm{pH}=7.4)$ at $37{ }^{\circ} \mathrm{C}$, was followed first order kinetics, due to the plotting of $\log$ (residual product concentration) versus time will give straight line, as illustrated in Figs. 1-4.

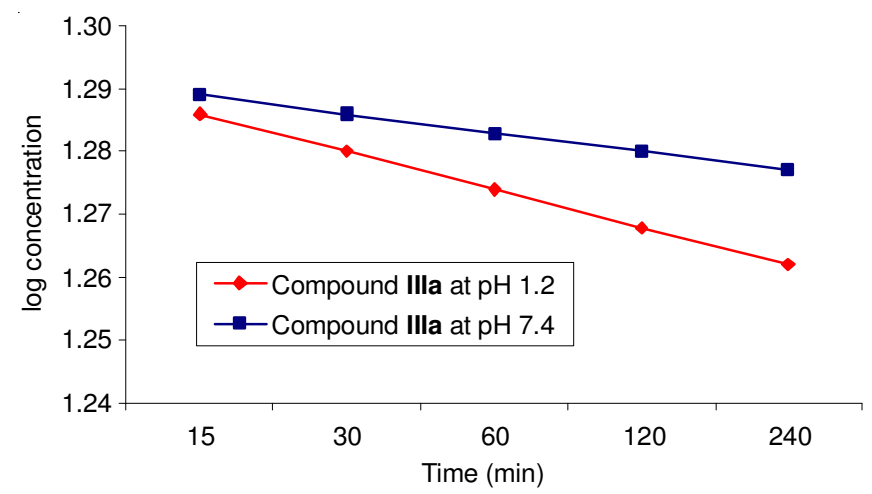

Fig. 1. Rate of hydrolysis of compound IIIa at different $\mathrm{pH}$ values

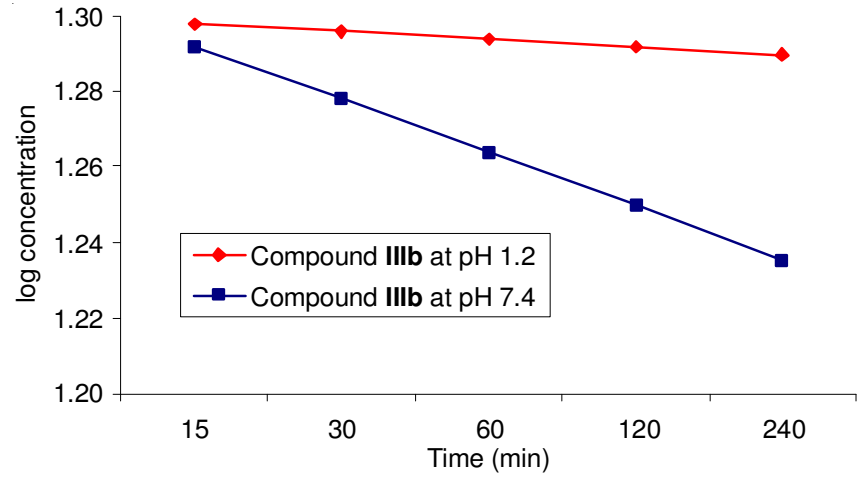




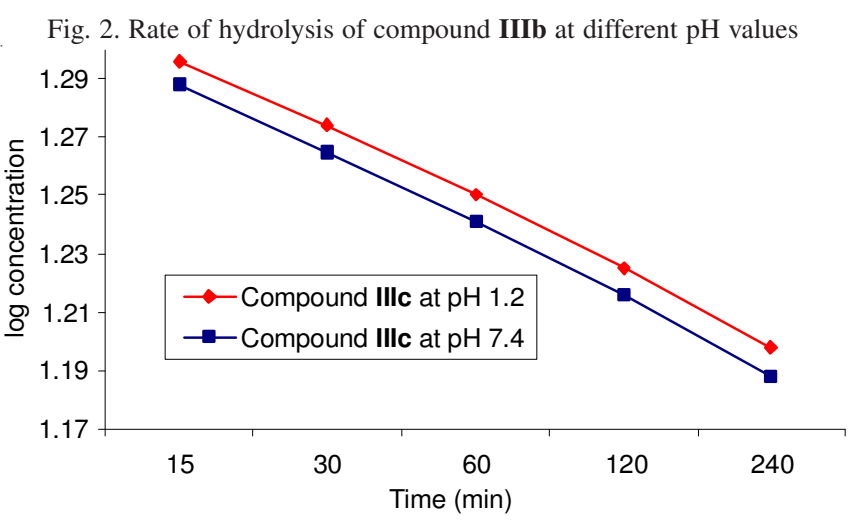

Fig. 3. Rate of hydrolysis of compound IIIc at different $\mathrm{pH}$ values

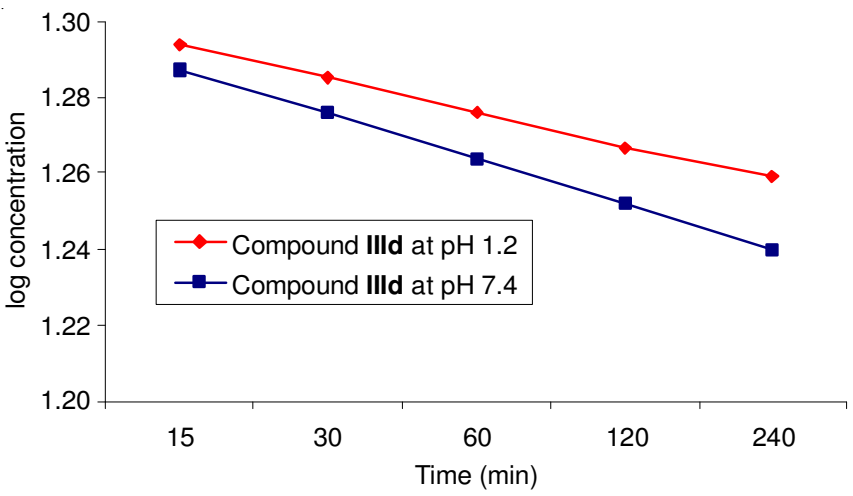

Fig. 4. Rate of hydrolysis of compound IIId at different $\mathrm{pH}$ values

The observed hydrolysis rate constant $\left(\mathrm{k}_{\mathrm{obs}}\right)$ was calculated from the straight line slope and accordingly the first order kinetic half life $\left(\mathrm{t}_{1 / 2}\right)$ was calculated from the following equation [45]:

$$
\mathrm{t}_{1 / 2}=0.693 / \mathrm{k}_{\mathrm{obs}}
$$

The data of the chemical hydrolysis of the four synthesized prodrugs were given in Table-2, which reveal the stability of synthesized prodrugs in ( $\mathrm{pH}$ 1.2) that similar to stomach environment and in $(\mathrm{pH} 7.4)$ that similar to intestinal environment.

TABLE-2

$\mathrm{k}_{\mathrm{obs}}$ AND t $_{1 / 2}$ FOR CHEMICAL HYDROLYSIS

OF THE FOUR SYNTHESIZED PRO-DRUGS

\begin{tabular}{cccc}
\hline Compound & $\mathrm{pH}$ & $\mathrm{k}_{\text {obs }}\left(\mathrm{min}^{-1}\right)$ & $\mathrm{t}_{1 / 2}(\mathrm{~min})$ \\
\hline \multirow{2}{*}{ IIIa } & 1.2 & $2.309 \times 10^{-3}$ & 300.13 \\
& 7.4 & $1.859 \times 10^{-3}$ & 372.77 \\
\hline \multirow{2}{*}{ IIIb } & 1.2 & $4.651 \times 10^{-4}$ & 1489.9 \\
& 7.4 & $1.346 \times 10^{-3}$ & 514.85 \\
\hline \multirow{2}{*}{ IIIc } & 1.2 & $7.721 \times 10^{-4}$ & 897.51 \\
& 7.4 & $2.00 \times 10^{-3}$ & 346.46 \\
\hline \multirow{2}{*}{ IIId } & 1.2 & $1.007 \times 10^{-3}$ & 688.18 \\
& 7.4 & $2.030 \times 10^{-3}$ & 341.37 \\
\hline
\end{tabular}

Enzymatic hydrolysis: The hydrolysis of the four synthe- sized gatifloxacin-NSAIDs prodrugs in $80 \%$ human plasma was followed first order kinetics, due to the plotting of $\log$ (residual product concentration) versus time will give straight line as illustrated in Fig. 5.

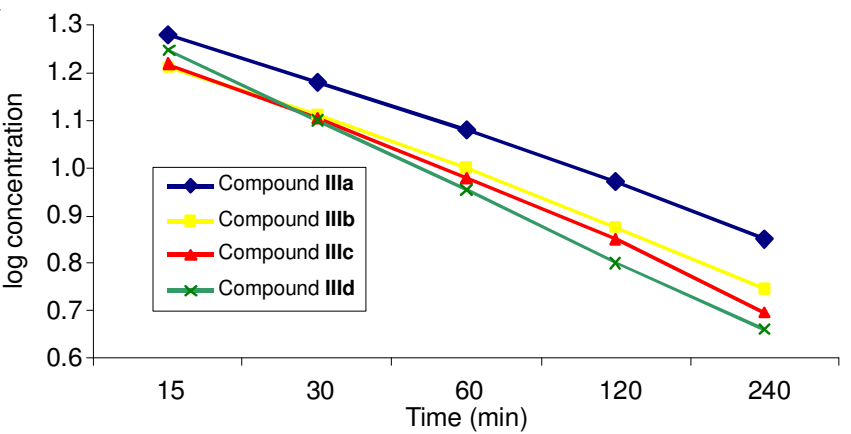

Fig. 5. Rate of hydrolysis of compounds IIIa-IIId in $80 \%$ human plasma

The data of the enzymatic hydrolysis of the four synthesized prodrugs were given in Table-3, which show the susceptibility of the synthesized compounds to hydrolysis by esterase in human plasma, the percent of hydrolysis about $40-55 \%$ in the first hour.

The most important criteria of mutual prodrugs is their stability in aqueous solution and gastrointestinal fluids (at different $\mathrm{pHs}$ ), but they must be readily hydrolyzed by esterase enzyme in human blood plasma [46].

\section{Conclusion}

The designed mutual prodrugs were synthesized successfully and their structures were confirmed and characterized using elemental microanalysis $(\mathrm{CHN})$, infrared spectroscopy (FT-IR spectra) and proton nuclear magnatic resonance $\left({ }^{1} \mathrm{H}\right.$ NMR), their purity was confirmed by their physical data (melting points and $\mathrm{R}_{\mathrm{f}}$ values). Preliminary kinetic study for the synthesized compounds was revealed their stability at $\mathrm{pH} 1.2$ and $\mathrm{pH}$ 7.4. They do not undergo chemical hydrolysis in gastrointestinal fluid, while they showed good hydrolysis in $80 \%$ human plasma, with about $50 \%$ hydrolysis in the first hour due to the effect of esterase enzyme.

\section{ACKNOWLEDGEMENTS}

The author is thankful to Department of Pharmaceutical Chemistry, Faculty of Pharmacy, University of Kufa, Kufa, Iraq for providing the facilities to complete the synthetic and kinetic studies.

\section{REFERENCES}

1. R.V. Ghadage, J. Biol. Scient. Opin., 1, 255 (2013); https://doi.org/10.7897/2321-6328.01327.

\begin{tabular}{|c|c|c|c|c|c|c|c|}
\hline \multirow{3}{*}{ Compound } & \multicolumn{7}{|c|}{$\begin{array}{c}\text { TABLE-3 } \\
\% \text { HYDROLYSIS, } \mathrm{k}_{\mathrm{obs}} \text { AND } \mathrm{t}_{1 / 2} \text { FOR ENZYMATIC HYDROLYSIS OF THE FOUR SYNTHESIZED PRO-DRUGS }\end{array}$} \\
\hline & \multicolumn{5}{|c|}{ Hydrolysis (\%) } & \multirow{2}{*}{$\mathrm{k}_{\mathrm{obs}}\left(\min ^{-1}\right)$} & \multirow{2}{*}{$\mathrm{t}_{1 / 2}(\min )$} \\
\hline & $15 \mathrm{~min}$ & $30 \mathrm{~min}$ & $60 \mathrm{~min}$ & $120 \mathrm{~min}$ & $240 \mathrm{~min}$ & & \\
\hline IIIa & 5.4 & 24.35 & 40.0 & 53.0 & 64.6 & $3.688 \times 10^{-3}$ & 187.86 \\
\hline IIIb & 18.5 & 35.60 & 50.0 & 62.6 & 72.0 & $1.363 \times 10^{-2}$ & 50.80 \\
\hline IIIc & 17.6 & 36.60 & 52.6 & 64.5 & 75.0 & $1.290 \times 10^{-2}$ & 53.69 \\
\hline IIId & 12.0 & 37.00 & 55.0 & 68.5 & 77.0 & $8.635 \times 10^{-3}$ & 80.25 \\
\hline
\end{tabular}


2. A. Abu-jaish, S. Jumaa and R. Karaman, Prodrugs Overview, In: Prodrugs Design-A New Era, Nova Publisher, USA, pp. 7-102 (2014).

3. B. Jolanta, Pharmacol. Rep., 65, 1 (2013); https://doi.org/10.1016/S1734-1140(13)71253-2.

4. S. Shirke, S. Shewale and M. Satpute, Int. J. Pharm. Chem. Boil. Sci., 5, 232 (2015)

5. N. Sharma, A.K. Sahdev and V. Raj, Org. Med. Chem. Int. J., 2, 1 (2017); https://doi.org/10.19080/OMCIJ.2017.02.555586.

6. S. Ohlan, S. Nanda, D.P. Pathak and M. Jagia, Int. J. Scient. Sci. Res., 2, 719 (2011).

7. S.S. Dhaneshwar, D. Bhosle, S. Bharambe and N. Gairola, Indian J. Pharm. Sci., 68, 286 (2006);

https://doi.org/10.4103/0250-474X.26654.

8. S. Ramakrishna, V. Mihira, K.R. Vyshnavi and V. Ranjith, Int. J. Curr. Pharm. Res., 4, 90 (2012).

9. P. Datar and T. Shendge, Chem. Inform., 1, 1 (2015).

10. I. Perkovic, Z.R. Dzolic and B. Zorc, Acta Pharm., 63, 409 (2013); https://doi.org/10.2478/acph-2013-0023.

11. M.F. Mahdi, N.H. Naser and N.H. Hammud, Int. J. Pharm. Pharm. Sci., 9, 66 (2017); https://doi.org/10.22159/ijpps.2017v9i7.18273.

12. M.F. Mahdi, A.-M.R. Raauf and N.M. Mohammed, Eur. J. Chem., 6, 461 (2015); https://doi.org/10.5155/eurjchem.6.4.461-467.1321

13. I.Q. Abdulla, Nat. Sci., 6, 47 (2014); https://doi.org/10.4236/ns.2014.62008.

14. K. Dweib, S. Jumaa, A. Thawabteh, L. Scrano, S.A. Bufo, G. Mecca and R. Karaman, World J. Pharm. Pharmaceut. Sci., 4, 1960 (2015).

15. S.L. Abdulhadi, A.J. Qasir and N.A. Abdul Razzak, Iraqi J. Pharm. Sci., 22, 22 (2013).

16. M. Asif, Res. Rev.: J. Chem., 4, 28 (2015).

17. S. Saleh, M. Mohammad, S.H. Mashallah, E. Elayeh, I. AlMasri, H.S. Al-Khatib, M. Fararjeh and Y. Bustanji, Sci. Res. Essays, 7, 310 (2012); https://doi.org/10.5897/SRE11.126.

18. G. Sarkozy, Vet. Med.-Czech, 46, 257 (2001).

19. V. Yadav, S. Sultana, J. Yadav and N. Saini, PLoS One, 7, e47796 (2012); https://doi.org/10.1371/journal.pone.0047796.

20. M.H. Mohammed, M.F. Mahdi, N.H. Naser and S.M. Ali, J. Nat. Sci. Res., 5, 106 (2015).

21. F. Shamsa, A. Foroumadi, H. Shamsa, N. Samadi, M.A. Faramarzi and A. Shafiee, Iran. J. Pharm. Res., 10, 225 (2011).

22. T.J. Dougherty, A. Nayar, J.V. Newman, S. Hopkins, G.G. Stone, M. Johnstone, A.B. Shapiro, M. Cronin, F. Reck and D.E. Ehmann, Antimicrob. Agents Chemother, 58, 2657 (2014); https://doi.org/10.1128/AAC.02778-13.

23. P.M. Hawkey, J. Antimicrob. Chemother., 51, 29 (2003); https://doi.org/10.1093/jac/dkg207.
24. P.C. Sharma, A. Jain and S. Jain, Acta Polon. Pharm.-Drug Res., 66, 587 (2009).

25. J. Xia, Y. Zhao, H.-H. Chen and J. Wang, Saudi Med. J., 34, 829 (2013).

26. S.K. Raul, B. Shanmukha and D. Jhansi, Int. J. Pharm. Pharm. Sci., 7, 121 (2015)

27. M. Zhao, B. Song and Y. Liu, Biomed. Res., 28, 3501 (2017).

28. K. Soni, Indo Global J. Pharm. Sci., 2, 43 (2012).

29. P. Yadav, P. Deolekar, V. Kanase and S. Mishra, Int. J. Pharm. Pharm. Sci. Res., 3, 2472 (2012).

30. S.M. Uriarte, R.E. Molestina, R.D. Miller, J. Bernabo, A. Farinati, K. Eiguchi, J.A. Ramirez and J.T. Summersgill, Antimicrob. Agents Chemother., 48, 2538 (2004); https://doi.org/10.1128/AAC.48.7.2538-2543.2004.

31. N. Sultana, M.S. Arayne, A. Naz and M.A. Mesaik, Chem. Cent. J., 7, 6 (2013); https://doi.org/10.1186/1752-153X-7-6.

32. A. Kumar, Indian J. Pharm. Pharmacol., 2, 16 (2015).

33. N. Madhavi and B. Lourdu Rani, Int. J. Pharma Bio Sci., 4, 951 (2013).

34. N.A. Md Daud, M.Sc. Thesis, Novel Developments for Increased Efficacy and Longevity of Existing Clinicaly Approved Antibiotics. University of York, England (2012).

35. A.K. Hussein, N.H. Nasser, A.H. Abdulsada and S.A. Hasan, Der Pharma Chemica, 8, 89 (2016).

36. A.B. Talib, M.F. Mahdi and M.H. Mohammed, Int. J. Compreh. Pharm., 12, 1 (2010).

37. V. Bharat, Der Pharma Chemica, 6, 347 (2014).

38. R.M. Silverstein, F.X. Webster and D.J. Kiemle, Spectrometric Identification of Organic Compounds, John Wiley \& Sons Inc., USA, edn 7, pp. 72-108 (2005).

39. R.M. Silverstein, F.X. Webster and D.J. Kiemle, Spectrometric Identification of Organic Compounds, John Wiley \& Sons Inc., USA, edn 7, pp. 144-2014 (2005).

40. J. McMurry, Organic Chemistry, Thomson Learning Inc., USA, edn 7, pp/ 794-811 (2008).

41. M.B. Smith and J. March, March Advanced Organic Chemistry, John Wiley \& Sons Inc., New Jersey, USA, edn 6, pp. 425-656 (2007).

42. M.A. Fox and J.K. Whitesell, Organic Chemistry, Jones and Barlett Publisher Inc., Canada, edn 3, pp. 376 (2004).

43. D. Cairns, Essentials of Pharmaceutical Chemistry. T.J. International, Padstow, Cornwall, Great Britain, edn 3, pp. 59-79 (2008).

44. J. McMurry, Organic Chemistry, Thomson Learning Inc., USA, edn 7, p. 808 (2008).

45. B.A. Mechael, Kinetics of Product Stability, In: Pharmaceutics the Design and Manufacture of Medicines, Elsevier Limited: New York, NY, USA, edn 3, pp. 99-107 (2007).

46. D.H. Jornada, G.F. dos Santos Fernandes, D.E. Chiba, T.R.F. de Melo, J.L. dos Santos and M.C. Chung, Molecules, 21, 42 (2016); https://doi.org/10.3390/molecules 21010042. 